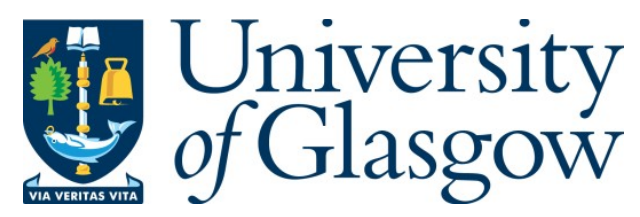

Atkinson, C., Mcbride, M. and Moore, A. (2021) Pitched! Informants and the covert policing of football fans in Scotland. Policing and Society, 31(7), pp. 863-877.

(doi: $10.1080 / 10439463.2020 .1795168)$

This is the Author Accepted Manuscript.

There may be differences between this version and the published version. You are advised to consult the publisher's version if you wish to cite from it.

https://eprints.gla.ac.uk/221131/

Deposited on: 23 July 2020

Enlighten - Research publications by members of the University of Glasgow http://eprints.gla.ac.uk 


\title{
Pitched! Informants and the covert policing of football fans in Scotland
}

\author{
Colin Atkinson, University of the West of Scotland \\ Maureen McBride, University of Glasgow \\ Allan Moore, University of the West of Scotland
}

\begin{abstract}
This paper offers a new perspective on the policing of football fans by exploring the recruitment and use of 'informants', or 'Covert Human Intelligence Sources' (CHIS), in this area of police practice. Drawing upon semi-structured interviews with both football fans and police officers in Scotland we foreground fan experiences against a backdrop where intensive police surveillance has become a routine feature of football events. In particular, our research uniquely provides accounts of fans whom the police sought to recruit as informants, a process known colloquially in policing as being 'pitched'. In doing so we highlight the impact this tactic has on football fans, both individually and collectively. In understanding police perspectives, we note how the use of informants in football policing is frequently justified as a 'legitimate' means to provide intelligence to prevent violence and disorder amongst fans. Cautioning upon the dangers of further 'surveillance creep', we highlight that the use of informants in the policing of football fans and events raises both practical and ethical issues. In particular, we argue that the use of informants in the covert policing of football fans, if this tactic is to be used, must be grounded in a clearly articulated threat of violence and disorder that is accepted by football fans and the wider community. In the absence of this, the use of such tactics is likely to be considered unnecessary and disproportionate by football fans, feeding a wider narrative of criminalisation and a perception of illegitimate and disproportionate forms of policing.
\end{abstract}

\section{Keywords}

Football, policing, covert policing, informants, surveillance

\section{Introduction}

The use of 'informants' - who are oftentimes pejoratively termed grasses, touts, snitches, or rats has become a mainstay of contemporary policing in the United Kingdom (UK) as agencies seek to tackle a range of crimes. Informants, or to give them their UK legislative nomenclature 'Covert Human Intelligence Sources' (CHIS), are recruited in policing and law enforcement to covertly provide information on particular subjects, persons or other entities of investigative interest. Recent media reporting has alleged that police officers in Scotland have been active in attempting to recruit football fans as informants in order to secure intelligence on the movements and intentions of their fellow supporters (Hutcheon, 2018). Such developments, however, remain unexplored in academic research in Scotland or elsewhere. Nevertheless, the policing of football in Scotland, more broadly considered, has been subject to previous criminological inquiry: from Coalter's 1985 study of crowd behaviour at football matches (Coalter, 1985) to, two decades later, Megan O'Neill's sociologically informed and ethnographically rooted account of the interaction between police officers and football supporters (O'Neill, 2005). More recent scholarly attention has focussed upon the impact of new legislation in 2012, specifically the Offensive Behaviour at Football and Threatening Communications (Scotland) Act, which has been argued to have intensified police surveillance practices (McBride, 2017; Hamilton-Smith et al, 2019) and deepened the criminalisation of football fans in Scotland (Lavalette and Mooney, 2013; Law, 2016).

Despite the extensive and still growing literature on the policing of football in Scotland, and a plethora of research covering this matter elsewhere in the UK and beyond - particularly evident in the work of Clifford Stott (2014), Stott and colleagues (see Stott et al, 2012; Stott et al, 2018; Stott et al, 2019) and others (see Winter, 2016; Brechbühl, 2017; Testa, 2018; Laursen, 2019) - there has been a lack of attention given to the role of the informants in such contexts. More recent 
innovations elsewhere, such as the use of dialogue-based and explicitly non-coercive 'Police Liaison Teams' (Hoggett and West, 2018; Stott et al, 2018), and the practical use of legal instruments such as football banning orders (Hamilton-Smith and Hopkins, 2013; Hopkins, 2014), have attracted scholarly interest; but the role of police informants has been neglected in comparison. The neglect is perhaps perplexing given the deep history of the use of informants in other forms of policing, but possibly less surprising when situated in the context of a more general paucity of academic research on the use of this tactic (see Atkinson, 2019). Certainly, despite the long-held proclivity in policing to use covert human informants (Innes, 2000, p 358; Schreiber, 2001, p. 301) academic inquiry on this important topic remains circumscribed, not least due to the difficulties of researching this hidden area of policing (see Norris and Wilson, 2016). As Basia Spalek (2014, p. 831) has succinctly asserted, research into the role and use of $\mathrm{CHIS}$ is rare.

Addressing this gap, we offer a new perspective on the policing of football events and football fans in Scotland by exploring the use of informants in this context. In particular, our research considers football fans who have been 'pitched'; a colloquial term used in policing to describe the 'structured covert approach by a police officer, whose capacity is known to the person approached, to become a CHIS' (Police Scotland, 2016, p. 9). We seek to extend our analysis beyond the encounter itself, and to use this to shed light on issues of law, practice and ethics. In doing so, and reflecting the importance of both players in a given social interaction, and their interplay, we draw upon data from semi-structured interviews across two main groups: police officers and other security practitioners involved in the policing of football (including those who have experience in the recruitment of informants and the use of this intelligence), and football fans themselves (including those with direct experience of attempts to recruit them as informants). In foregrounding fan experiences, our research uncovers, against a backdrop of intensive policing and surveillance, not only the 'pitching' of fans but also the disruptive and unsettling effect that this tactic can have on those fans who are pitched. In understanding policing perspectives, our research indicates that the use of informants is frequently justified by the police service as a means to provide actionable intelligence to prevent violence and disorder. However, in our discussion we caution upon the dangers of 'surveillance creep', particularly in a context where violence and disorder at and around football events is not a routine occurrence. The use of informants here thus raises both practical and ethical issues, with the clear potential to exacerbate perceptions of criminalisation amongst football fans and erode trust in the police. Before developing these findings, this paper begins with an overview of the relevant literature and a description of the research methods used to produce the findings.

\section{Literature review}

This section will focus upon the literature on the intelligence-led policing of football events. 1 Research on the policing of football has been somewhat overshadowed by a fixation on the folk devil of the 'football hooligan' as part of the wider social and political construction of 'hooliganism' (Maguire, 2006). Whilst hooliganism has been classically considered in the literature as an 'English disease' (see Stott and Pearson, 2007), academic research has considered this phenomenon in a diverse range of jurisdictions, including, but not limited to, Italy (Domizio and Caruso, 2015), the Netherlands (Spaaij, 2007), Sweden (Andersson, 2001), Poland (Kossakowski, 2017) and Brazil (Newson et al., 2018). Recognising the nuance of national contexts, and in particular the tendency to subsume Scotland within the English milieu, the scholarship of HF Moorhouse (1984; 1987; 1991; 2006) repeatedly documented the need to consider the evidence of the distinctive Scottish experience of football and any associated 'hooliganism'. 2 Subsequent scholarship that specifically addressed Scotland in fact acknowledged that football-related disorder here, and efforts to tackle this issue, preceded developments south of the border (O'Neill, 2005).

Various moral panics over the behaviours of football fans across time have been used to justify the use of policing practices (see Whannell, 1979; Rookwood, 2017). Most recently, such policing has 
involved the use of particular surveillance tactics, including covert methods, previously employed in the 'high policing' of terrorism and organised crime (see Brodeur, 2007). Over a decade ago, Anastassia Tsoukala $(2009$, p. 81 ) remarked upon the use of such tactics by police forces in the UK to tackle football hooliganism, including the deployment of undercover officers and the use of telephone hotlines to receive information. Noting the use of police intelligence-gathering techniques as part of a wider panoply of tactics, James and Pearson traced the development of the policing of football fans over the past six decades,

Football supporters are amongst the most heavily policed social groups in the UK. Since the late 1960 s, the policing of football crowds has evolved to include as a matter of routine restrictions on movement, the use of stop and search provisions, and various invasive intelligence-gathering techniques. It was also in the football context that the first civil preventive orders were developed. (James and Pearson, 2015, p. 458).

Signalling the continuation of intelligence-gathering approaches, as part of the intensification of riskbased policing practice, Stott et al. recently remarked,

It is often assumed that football 'disorder' is the outcome of the convergence of groups of fans predisposed toward conflict (i.e. 'hooligans'). Accordingly, the very presence of these fans is anticipated to pose a 'risk' to 'public order'. Therefore, police guidance at a national and international level revolves around the categorisation of fans as either 'risk' or 'non-risk' ... Within the UK the task of identifying 'risk' fans is an assignment undertaken primarily by Football Intelligence Officers (FIOs) and 'spotters'. (Stott et al, 2018, pp. 2-3).

Such developments are important because just as hooliganism and football-related disorder have been considered as originating in Britain, so the 'British' model of policing this issue since the 1990s has gained international traction (Garland and Rowe, 1999, p. 36). As Lise Joern argued in 2009, in the context of the forms of surveillance and control of football fans that had been implemented or were being considered in Denmark,

Just as Danish supporters have taken on board elements of English fan culture (both positive and negative), so do the Danish authorities look in that direction in the same quarter when devising strategies to combat anti-social behaviour. (Joern, 2009, p. 1270).

Similarly, Tsoukala remarked upon the wider European context, offering an explanation for the adoption of the 'British model': its early development. For her,

The first countries to have intelligence units specifically devoted to football hooliganism thus found themselves best placed because, by requiring other European countries to create posts and adopt practices that were similar to their own, their agents were able to impose de facto their own pattern of policing. In this quest for power, which relied on dissemination of a national model of social control, together with its underlying definition of the phenomenon to be controlled, it was the British security agents who, by setting up their own model for all the other European countries to follow, quickly achieved hegemony. (Tsoukala, 2009, p. 80).

In the context of such typical 'policy transfer' (Spaaij, 2015, p. 45-46), the requirement to highlight and understand the strategies and tactics used in the policing of football fans in the UK, recognising the potential for distinctiveness in different jurisdictions within the UK, becomes increasingly relevant internationally.

Whilst the policing of football events and fans in Scotland has become subject to increasing social and political interest in recent times, bringing to bear upon fans a particularly intense legislative and 
policing regime, academic research on this form of policing here has deeper roots. In a 2004 article, based on her ethnographic study of this subject, Megan O'Neill argued that within Scottish policing there existed a distinct sub-culture of the policing of football (O'Neill, 2004). O'Neill's research provides important insights, but it must be recognised that her 2004 work and her subsequent booklength study (2005) are based primarily on research carried out 20 years ago. A plethora of important developments have occurred in the period since: in Scottish policing through police reform; in the wider legislative landscape, with the implementation and subsequent repeal of legislation particularly targeting football fans; and even in football fan culture itself, with the increasing influence of expressions of fandom more routinely found in other parts of Europe. Expanding on these developments, Scotland has recently created a new centralised police service, merging the previous regional forces and which became operational in 2013 (see Fyfe, 2016). The policing of football in Scotland has become increasingly politicised, most notably manifest in the controversial, and ultimately ill-fated, Offensive Behaviour and Threatening Communications (Scotland) Act 2012, which before its repeal in 2018 created new criminal offences in Scotland concerning 'sectarian' behaviour in relation to football matches. McBride summarised the genesis of the Act,

Legislation aimed at tackling the allegedly sectarian or otherwise offensive behaviour of football supporters was proposed at a summit in the immediate aftermath of a high-tension match between Celtic and Rangers in March 2011, though it is important to note that actual disorder amongst fans at the match was minimal. (McBride, 2017, p. 234).

McBride further reflected upon the criticisms of the Act, including concerns about the discriminatory targeting football fans as a social group, particularly younger supporters, alongside concerns over policing practices, including intensive surveillance, that have resulted in a breakdown in trust between supporters and the police (McBride, 2017. p. 237). Since the repeal of the Act the interrelated topics of fan behaviour and policing have remained high on the Scottish political agenda; resulting in an independent review carried out by a senior police officer from an English force (see Roberts, 2019). James and Pearson (2015) further highlight how football fans in the UK have, to an extent, acquiesced to their effective criminalisation, particularly in comparison to other protest groups. 3 More recently in Scotland, however, football fans have mobilised against their increasing criminalisation as they have become subject to intensive regimes of policing and surveillance based on the construction of 'risk' in what effectively amounts to a 'hot' political climate (Loader and Sparks, 2011). The role of informants in such policing, however, has only recently been brought to public attention.

There has been an upturn in research on the role of informants in policing and law enforcement since the turn of the millennium, yet it remains difficult to challenge the contention that social scientists have 'largely ignored' this policing tactic (see Miller, 2011). 4 Crucially, existing research on the policing of football has thus far failed to feature the informant as a subject of empirical investigation or analysis. There has, however, been discussion in the literature of the policing of football upon the wider suite of covert tactics used to tackle the types of crimes routinely associated with, or attributed to, football fans, matches or events. As Stott, Pearson and West have recently noted,

The approach to policing the crowds attending fixtures of Football Leagues of the UK relies heavily upon network of 'spotters' who provide surveillance and intelligence-gathering on football fans across every season. In the planning phases of football policing operations this intelligence is used by the host force to estimate the threat posed by fans. (Stott, Pearson and West, 2019, p. 3) 
The use of spotters at football matches and, more broadly, their use against football fans in order to gather intelligence, is also a recognised policing tactic in Scotland. The use of informants sits comfortably within this previously emergent, and now well-established, intelligence-led policing paradigm that privileges risk-based strategy and surveillance-intensive - and sometimes covert practices. Nevertheless, the extent to which the use of informants has permeated the policing of football in either Scotland, the UK or beyond remains, at best, unclear. Snippets of the use of informants in the policing of football can be found in autobiographical accounts of former officers and media reporting of contemporary policing. In relation to the former, Michael Layton recounts his time as police officer in England in the 1980s, running an informant into a group of Birmingham City fans implicated in football-related violence and wider disorder (Layton and Endeacott, 2015). 5 Recent media reporting in Scotland, however, has brought this issue into sharp focus. On 9 September 2018, a Scottish newspaper, The Herald, published an article under the headline 'Police Scotland accused of trying to turn young football fans into paid informants'; with the news item reporting the direct experiences of three fans of three different Scottish football clubs of being 'pitched' to report on their fellow fans and football-related issues (Hutcheon, 2018). This media reporting brought this issue into the public purview, albeit fleetingly, and galvanised our research interest in the covert policing of football fans in Scotland.

\section{Research methods}

This paper offers a new perspective on the policing of football and football fans in Scotland by exploring covert policing tactics, and specifically the use of informants and practices of informant recruitment. It is principally informed by data from semi-structured interviews with 31 participants conducted in 2019. The semi-structured interviews were conducted with football fans in Scotland, including those who have been 'pitched', as well as with police officers and other security practitioners involved in the policing of football, including those who have experience in the recruitment of informants and the use of this intelligence. Participants were identified through a convenience sampling procedure drawing upon the existing networks of each of the three authors, supplemented where possible by snowball sampling to extend beyond these networks. This approach, which has been used elsewhere in the limited existing research in the study of police informants (see Miller, 2011), was justified given that the research effectively sought to engage with two distinct 'hidden populations'. For Heckathorn,

"Hidden populations" have two characteristics: first, no sampling frame exists, so the size and boundaries of the population are unknown; and second, there exist strong privacy concerns, because membership involves stigmatized or illegal behavior, leading individuals to refuse to cooperate, or give unreliable answers to protect their privacy. (Heckathorn, 1997, p. 174).

Such an assessment certainly applies to those who have been approached by the police to become informants; individuals to whom there generally remains a significant level of social stigma and the threat of violent retribution from peers or ostracization for their communities (Innes, 2000, p. 361). The challenges of identifying and engaging with such individuals may, at least in part, explain the paucity of empirical research in this particular domain. 6 Whilst the police service may, upon an initial reading, seem less 'hidden' in comparison, the sub-field of covert policing is constituted by some of the most sensitive and closely guarded areas of police work, and these settings can oftentimes be physically off-limits to the academic researcher (see Mac Giollabhuí et al, 2016, p. 633). 7 In such contexts, the covert policing practitioners with whom the research particularly sought to engage constituted a de facto hidden population, even though their status may not necessarily be characterised by the forms of stigma or illegality outlined by Heckathorn. The data produced through the 31 semi-structured interviews conducted for this study was transcribed by the researchers where ethically and practically possible, with relevant data - including sub-sets of data from two 
precursor studies - imported into the NVivo qualitative data analysis software package for coding and subsequent thematic analysis.

Additionally, the research was also able to draw upon, where it was illustrative to do so, data from two precursor projects. The first of these was a study of the intersection between police informant work and new forms of intelligence analysis in Scotland, based upon data from 19 interviews with police practitioners conducted in 2017 and 2018 (Atkinson, 2019). The second precursor project was the doctoral study of the second author: a qualitative exploration of sectarianism and the meanings and experiences of football supporters in Scotland, based on data from 30 interviews conducted in the period from 2015 to 2017 (McBride, 2018). The ability to draw upon these precursor projects enriched the analysis herein through both the provision of additional relevant data, as well as facilitating a deeper contextual analysis in which to embed the findings on the use of informants and the covert policing of football fans in Scotland.

This overall approach to research design and analysis captures recent developments in the policing of football in Scotland, and given the similarities in the legislative, policing and cultural contexts the research is also likely to provide some useful insights for the policing of football in England and Wales (see Hamilton-Smith and Hopkins, 2013). Broader international comparisons, however, may be more difficult to sustain, given the limited number of interviews, the convenience sampling procedure, and the particular societal and cultural contexts in which the study took place. Nevertheless, there are some sound reasons for assuming some international relevance, particularly given that the extant literature has highlighted how the 'British model' of both hooliganism and policing has gained traction elsewhere. Overall, this paper addresses an enduring and still relevant call for the rigorous, research-based, study of the practical aspects of police informant work, and the processes and methods that underpin current systems (Billingsley, Nemitz and Bean, 2001, p. 22-23). The policing of football in Scotland presents an illustrative case study from which to develop new knowledge, insights and perspectives in this important area of contemporary police work.

\section{Foregrounding fan experiences}

This current decade in Scottish football has signalled a seismic shift in relations between football fans and clubs, policing agencies, stewarding companies, and the Scottish Government. A confrontation between staff of both clubs at a Celtic versus Rangers match in early 2011, a particular fixture subsequently dubbed the 'shame game', was followed by a series of developments that established a toxic backdrop for experiences of security at and around football events. A moral panic over the issue of 'sectarianism' in Scottish football immediately ensued, followed by the development and introduction of the Offensive Behaviour at Football and Threatening Communications (Scotland) Act 2012; the targeting of football fans across Scotland by the nation's new police force using surveillance-intensive tactics and technologies; the creation of a grassroots campaign by football fans against this legislation and the ensuing policing tactics, culminating in the repeal of the Act in 2018; the establishment an independent review of the policing of Scottish football following a 'crushing' incident at the turnstiles of a Scottish football stadium in September 2018; and a continuing campaign by politicians and stakeholders to highlight perceived 'disorderly' fan behaviour and appropriate responses, including the introduction of strict liability for football clubs and the requirement for new legislation. An appreciation of this background context is essential in understanding attempts by police officers in Scotland to recruit football fans as covert informants.

Whilst this paper draws upon a broad and deep evidence base, our research importantly uncovered the experiences of two fans who were recently pitched by Scottish police officers with the aim of recruiting them as informants in order to provide the police with intelligence on their fellow fans. Despite supporting different clubs these two fans shared common profiles: being of a similar 
demographic and both heavily involved in organising the activities of fan 'ultras' groups attached to their respective clubs. Their separate accounts of the circumstances of how they were pitched overlap significantly, lending credibility to their claims. For Tony,

I'd never spoken to a police officer at the football in easy five years, but my mum phoned me [to say] that there was two police officers at her's [the parental home] to see me ... she said they are asking you to come here right now, and they were saying we know Tony is a great kid but he might have some influence on the younger supporters ... They drove to me in an unmarked car ... They asked me to jump in the car, and said 'we know you and your pals don't cause any bother, but there is a young group around 15, 16 and we think they are going to cause a lot of bother, in fact we've actually heard in one instance that there was a boy carrying a knife to the game, do you know anything about this?' And I was like 'nup, I know nothing about this'. And they said 'we think you might be someone they look up to, you've been painting banners and flags for years, would you be able to speak to them for us and be able to find out how they are travelling to away games, what their plans are and how they are getting there, what they are up to during the week, if they are phoning people and arranging to meet other groups of supporters?' ... [After refusal] they said this is very serious and there can be rewards for giving information. I was like 'is this a wind up, what police station are you from?' They said we canny tell you. (Tony, football fan)

Tony elaborated upon the type information that the police officers were seeking, at least initially, to gather from this prospective relationship,

[The police officers wanted me to] Engage with younger fans to give them [the police] information, and help them with their policing. The way they tarted this up was by saying this would be better for everyone involved. 'If you tell us on a Thursday that there is only 15 fans going then we will only deploy two police officers and you won't then turn up and there is ten police officers for 15 fans' ... [They wanted to know] Who is going [to the match], how they are travelling, what is their route going to be, when are they setting off? (Tony, football fan).

Andrew, who was pitched during the same football season as Tony, expressed a similar account,

The police turned up at my door one day and asked if it was alright to come in for a wee chat ... They said 'we love what you are doing down there, we know you are not out to cause any trouble, but there is a small minority within the group who have caused bother and things are happening, if I was to leave my number would you tell me information? Have you got any problems with people inside the group, or any names you don't want associated with you and we can look at getting football banning orders.' They said you know, 'if I leave my name and email address, people respect you, if you were to hear anything about something happening would you send us a text message?' They were even asking stupid stuff like how many fans were travelling to a game from like our group, and 'how are yous getting up there?' like trains and stuff, 'because it means we don't need to put as many resources out' and following four or five of yous about for nothing ... They said anything you could do to help us, that would be really good. They were like nicey-nicey. I'd never experienced the police trying to be nice to me! (Andrew, football fan)

Andrew suggested that he suspected that similar approaches were made to fans at 'four or five different clubs' around the same time that he was pitched. Whilst both Tony and Andrew independently recounted that the police officers who approached them were 'nice', both reflected upon the unsettling nature of their experience of being pitched. For Tony this was manifest in how his mum was 'terrified' and 'totally worried', given that the initial approach was made at her home and that her son had never been in trouble with the police. For Andrew, who told his fellow fans of 
the approach 'straight away', his pitch had a disruptive effect on their relationships: some fellow fans found it 'funny', whilst others found it 'fishy' and suspected he was 'a grass'.

The use of this tactic can be understood against a backdrop where the use of both covert and overt surveillance, as well as other forms of police intelligence-gathering tactics, had become a routine feature of football policing. In relation to the latter, previous research by one of the authors (McBride, 2018) revealed various instances of police approaching football supporters in public places unrelated to the football context. Matthew, for example, explained that he was approached at an airport returning from a holiday, and felt he was recognised by police because of his involvement in an 'ultras' group. He described being singled out by police who would 'name drop' to make it clear that he was known to them,

He [the police officer] walked past me saying, "Hello Matthew, how are you doing, how's your girlfriend, how's your kids?" They go up to your workplace, they arrest people at airports, and they're found not guilty!" (Matthew, football fan). 8

Similar practices were recounted in research undertaken specifically for this paper, particularly uncovering perceptions that police officers were trying to 'fish' for information from fans. For example one fan, Terry, explained that he was at a train station after attending what would be described as a 'high risk' match when he was approached by two police officers, who began 'trying to talk' to him and ask questions about the post-match plans of the away supporters. Terry also suggested that this was part of a broader pattern of suspicious encounters where 'intelligence' was being increasingly gathered on a very casual basis; citing examples of police officers who know him (including one to whom he is related) making conversation with him about upcoming matches while he was in the gym and on the street away from any football context. Overlaying such concerns, there was also evidence that fans were concerned about the complicity of clubs in such intelligencegathering arrangements, particularly given that club security officers were oftentimes former police officers. One supporter, Barry, who was a fans' group representative at his club, discussed how his club's initiative to encourage supporters to 'text us the bad behaviour of other fans' and the club's dissatisfaction in relation to a particular banner display that he was involved in planning were directly influenced by police concerns. Such instances are collectively indicative of the lack of trust between at least some football fans and the police in Scotland.

\section{Understanding police perspectives}

The use of informants in the covert policing of football fans - even as part of a broader suite of covert and overt police tactics - may, upon an initial assessment, seem disruptive to fan-police relations and disproportionate to the targeted 'criminality'. However, to fully understand this tactic it is necessary to explore police perspectives on its use in such contexts. For police officers the principal rationale for the use of informants in the policing of football has been, and remains, preventative: to gather information in advance on where potential violence or disorder may occur and deploy appropriate measures to disrupt any such 'hooliganism' before it takes place. An experienced officer with responsibility for managing an informant unit, Sam, remarked upon the comparison between a particular fixture in the past, where informants were not used and there was a level of disorder, and a more recent match between the same two teams where informants were deployed and disorder was minimal. For Sam,

The difference [for the second fixture] was the polis [police] were there to stop it ... the best feedback we got was from the match commander, who said 'the live time intelligence [from informants] was brilliant, we couldn't have worked without it. It would have been carnage'. (Sam, police officer) 
In this example, the role of informants was considered critical to stopping any disorder from occurring, across multiple locations, by feeding intelligence through appropriate channels and deploying uniformed officers and public order units appropriately as a preventative operational tactic. Whilst there was a frustration in this particular case that such successes were not necessarily visible or appreciated across the wider policing community, and that these outcomes could not be 'counted on a spreadsheet', there was a deep level of satisfaction amongst those officers engaged in such informant work that their efforts had made a difference to public safety. Any frustration was also mitigated by the understanding that senior police management was aware of the use and the effectiveness of such tactics, as well as the significant efforts of the officers responsible for handling the informants and delivering the intelligence.

Beyond this particular incident, the use of police informants to provide actionable intelligence on football fans to prevent violence and public disorder was frequently raised by police officers in our research. Michael, a police officer, provided a straightforward justification for the use of informants in relation to the underlying legislative principles of proportionality and necessity.

If we are getting planned disorder that the police are unsighted on through overt sources, then it is necessary to get CHIS into that. And if that planned disorder is compromising police and public safety then that is your proportionality. We've got to justify, and we can justify it ... We need to show that we've deployed all the usual measures, conventional policing tactics, but we've failed to collect the intelligence to prevent disorder. (Michael, police officer).

The words of another police officer, Nick, reflect the way in which this tactic has percolated from the 'high policing' of terrorism and organised crime to everyday 'low policing' (Brodeur, 2007); becoming a mainstream police response to crime and disorder,

We are intelligence-led. We will actively try and recruit CHIS to report on football. Why wouldn't we use an asset that we use in all areas of criminality to also help keep people safe at football matches? It's a tried and trusted method. (Nick, police officer)

The provision of information from covert informants was recognised as important in that it provided actionable intelligence on the day of the football match itself. Alexander, noted how 'local real-time intelligence is critical' in the policing of football, and that informants can play a key role in delivering this intelligence. Similarly, for Gary,

I know that we have got CHISs who are football supporters who are embedded ... Their intel is spot on. There and then, it can cut the trouble out before it's happening, [and] you can get the resources there at the right time. We've seen that tonnes and tonnes of times. (Gary, police officer)

The use of informants in such contexts was considered to be a 'legitimate policing tactic', and one that is subject to 'proper scrutiny and governance' (Michael, police officer). It is clear, therefore, that whilst the practice of using informants in the policing of football may not be particularly widespread - certainly other police officers who engaged in our research were unaware of the use, or the particular details, of this tactic - it is an approach to the policing of football fans that does occur and is valued in policing.

Whilst the rationale for the use of informants was predicated on the prevention of violence and disorder, it is important to note that our research did not suggest that violence and disorder at, around, or even linked to football events in Scotland was a routine or common occurrence. For Tony, a football fan and regular attendee at his club's match both home and away, the intrusive and intensive police surveillance tactics based on such assumptions were unmerited and misguided, 
What are they doing this for [recruiting and deploying covert informants]? What a waste of money, what a waste of time and resource. I'm like, why, what are you trying to achieve? ... I think it's absolute nonsense. I've seen first-hand, I canny remember the last time I went to the football and seen a fight at the football, and I've been every week in the last 15 years. It's bizarre. (Tony, football fan)

A counter-narrative could be constructed from a policing perspective that the lack of violence and disorder may, in fact, be due to the effectiveness of policing practices. For Nick, "I think the model we have got it right, because very rarely do we get issues at football matches" (Nick, police officer).

Yet Nick also noted that attending a football match in Scotland was a safe pastime, with any 'carnage' related to football fans occurring elsewhere in locations away from football stadiums that people don't see', for example in relation to increases in domestic violence in private dwellings or other issues 'in the pubs and clubs'. For another police officer incidents of violence and disorder in public but away from the match itself was where the value of intelligence, including intelligence from informants, could be found.

The intelligence side of things is all about organised disorder, and that is not inside the ground, that is outwith the ground. And that is where I have used CHIS product [intelligence from informants] on countless occasions, particularly around [mentions two football teams] casuals, and found that to be incredibly useful in getting the right resources in the right place to prevent disorder or at least to minimise it if it's going to happen. (George, police officer)

Yet even here George acknowledged that Scotland has 'never had the level of violence that England has had' and that it is important 'to be realistic' about that when considering a proportionate policing response. Such perspectives on the use of covert informants in the policing of football must be understood in the contexts of the current discourse and rhetoric of 'risk' in football policing and recent shifts in fan culture.

\section{Risk, ultras culture, informants}

The use of covert informants in the policing of football was justified by police officers as a method to respond to the problem of those who may engage in violence and disorder. Such individuals and groups were considered within the category of 'risk supporters'. The official Police Scotland policy on football policing defines 'risk' and makes a distinction between a 'risk supporter' and a 'non-risk supporter'. For Police Scotland, in its Football Policing Standard Operating Procedure,

3.4.1 The term 'risk' is used in relation to individuals who associate themselves to football with the intention of engaging in criminal activity often centred on communal violence.

3.4.2 Risk supporter - A person, known or not, who can be regarded as posing a possible risk to public order or antisocial behaviour, whether planned or spontaneous, at or in connection with a football event.

3.4.3 Non-risk supporter - A person, known or not, who can be regarded as posing no risk to the cause of or contribution to violence or disorder, whether planned or spontaneous, at or in connection with a football event. (Police Scotland, 2016)

In our research, the construction of 'risk' as pertaining to violence or disorder was instrumental in legitimising the use of police informants: 
Where you get an intelligence picture emerging around risk [supporters] around violence, particularly organised violence where two factions will be thinking about having some organised violence, that is where you up the ante around your intelligence gathering and that is where you might task out CHIS type sources, because obviously if there is planning in organised football violence there has got to be a planning process on that side. So there is going to be people talking about how they are going to do it, times, venues. And that is where your CHIS assets [informants] can come in useful, where you do get information about pre-ordained meeting points and you can then helpfully disrupt those activities. But that tactic would only be used if the threat and the risk are proportionate and merit that tactic. (Kevin, police officer).

Crucially, however, in the official police definition a 'risk supporter' is understood not only in relation to the potential for violence or disorder but also for 'antisocial behaviour', a term that has long been noted as controversial and contested, as elastic and contingent (see Millie, 2009). 9 This raises the issue that the use of covert informants against 'risk supporters' may broaden out from a focus on violence and disorder to include other acts that would not otherwise normally justify the use of such intrusive tactics. The elasticity of Police Scotland's own definitions of 'risk' and 'risk supporters' has particularly brought fan 'ultras' groups, from the police perspective at least, into the purview of such intelligence-led, covert policing tactics. This has included the targeting of individual 'ultras' to become police informants.

The recent emergence of ultras groups in Scottish football has witnessed groups of fans organising their activities together, drawing their inspiration from European football fan culture and with a proclivity towards fan-led organised chanting, instrumentation, banners, pyrotechnics and processions to stadiums. Outside of the immediate matchday, ultras are also known to engage in both acts of graffiti and stickering in the urban environment. Tracing the historical development of ultras as a broader movement in fan culture Doidge and Lieser (2018) usefully recount its origins in 1960s Italian football as a form of political protest using banners, chants and flags, through the 1980s and the decline of political influence and a focus on violence via the influence of British hooliganism. By the 1990s, catalysed by the popularity of Italian football on television, the ultras style had spread across south-eastern Europe, and then via both television and social media proliferated in the twenty-first century across other parts of Europe, and globally. Scottish football in particular has recently experienced the development of new forms of fan culture through the development of ultras groups. Craig, who supported a team that had not fully developed its own ultras remarked upon his experience of encountering ultras from other Scottish teams,

I'm all for the young team [fan ultras groups] ... I want singing and having an atmosphere. Our ground is like a morgue! ... I'm jealous of [mentions rival club], they've got a thriving group of fans, when we played them a group of young lads, about 300 of them, sung for the whole game. It's growing, it's definitely growing in Scotland, even in the lower leagues as well. Most clubs will have some sort of ultras group now. (Craig, football fan)

Whilst Craig recounts the positive aspects of this emerging culture, within policing there was a perception that this developing ultras style has brought both positive and negative aspects to Scottish football, and also how this new style overlaid pre-existing fan cultures, including a more traditional hooligan or 'casual' element in the fanbase of some clubs,

The fan culture [has changed] in Scotland, [at] Rangers and Celtic definitely, to a lesser extent teams like Aberdeen and Motherwell and some of the smaller clubs. I don't think fan culture at teams like Hibs have changed that much. Hibs have always had a causal element. I've jailed a few of the Hibs casuals. (Gary, police officer) 
Writing from the perspective of Scottish football, Lavalette and Mooney (2013) have noted confusion amongst many people when they encounter the term 'football ultras' and the propensity to consider 'ultras' as either synonymous with 'hooligan' or indicative of an engagement in far-right politics; neither of which assumptions they consider correct. The recent emergence of this ultras culture in Scotland, and the fact that it predominantly involves young people - a demographic group that has traditionally been considered 'police property' (see Bowling et al, 2019, p. 266) - has thus far resulted in both a limited understanding in policing of the culture's roots, aesthetic, politics, objectives. As a result, there has emerged a tendency in some policing quarters to view ultras as problematic, antisocial, potentially violent, and worthy of police attention. This police attention has included the use of covert informants against ultras.

It is important to note, however, that there was a recognition amongst some police officers in Scotland of a distinction between risk supporters and ultras. Michael noted that risk supporters, in contrast to ultras, would be more likely to engage in violence and be comprised of an older cohort,

You've got risk groups and you've got ultras, which is slightly different ... Risk is more about the recreational disorder, fighting. The ultras will not be bothered about fighting ... With [mentions club] you've got that older [risk group], they are 40s, 50s, they'll engage in disorder and all the rest of it [violence], but then you've got a young up and coming element [ultras]. And these two groups will not associate together at all. (Michael, police officer)

For James, ultras were less problematic from a policing perspective, and more likely to be involved in visible and audible expressions of fandom (although these behaviours may in themselves be sometimes involve particular offences), rather than violence,

The ultras aren't always the ones intent on causing problems. They are just out to enjoy themselves in a more visible, noisy way. Yeah it's instruments and flares, but it's not violence ... Letting off a flare is not the same as punching someone in the mouth. (James, police officer)

Yet, despite some recognition of the distinction between 'risk' and 'ultras' in Scottish policing, the covert tactics deployed against football fans in Scotland, including the pitch to become informants, were certainly not limited to those risk supporters involved in violence and disorder. Crucially, Tony and Andrew, the football fans in our research who were pitched to inform on their fellow fans, had no record of violence or disorder, but were active in ultras groups at their respective clubs. They also rejected the suggestion that the ultras group of which they were part were involved in any acts of violence or disorder.

\section{Discussion}

In comparison to new surveillance technologies, the use of informants, as a more traditional tactic, has received less academic attention. Nevertheless, the use of informants sits comfortably within the wider narrative and conceptual framework developed in the new study of surveillance and 'surveillance society' (see Lyon, 2001). Considering the use of informants in the policing of Scottish football, Gary T. Marx's concept of 'surveillance creep' provides a lens through which to understand this tactic, particularly as it has been extended beyond an engagement solely with those involved in violence and disorder. Marx (2005) developed the concept of 'surveillance creep' to account for the intensification of surveillance, which posits that once aroused, the surveillance appetite can be insatiable. Essentially, he explains that surveillance has a functional tendency to expand due to the increasing uses found for existing technologies, with rationales quietly extended without public debate or scrutiny. Decision-makers create the necessary political conditions for expansion through the lure of functionality, without recourse to ethical considerations. We posit that this has been the case in Scottish policing, where the use of informants in the policing of football fans has been used - 
albeit with perhaps noble intentions - to penetrate (and indeed generate) 'suspect communities' (see Pantazis and Pemberton, 2009) without a clear articulation, or particular understanding, of an underlying 'threat'.

The use of informants in policing is based on an applied legal framework and in any given circumstance any such use must be considered as both necessary and proportionate to the perceived crime or harm, with all other potential intelligence collection methods exhausted or discounted before its use is appropriate. In the absence of any clear and convincing articulation by the police of an underlying 'threat' of violence many football fans in Scotland, including but not limited to those who are active in an emerging ultras culture and those categorised as 'risk' by the police service, perceive themselves to be targeted and criminalised by this tactic. From a pragmatic perspective, it seems counter-intuitive to use tactics that cause a further distancing between fans and the police. In fact, the use of more communicative and dialogue-based approaches to the policing of football has been gaining traction in other European countries, producing positive results (see Laursen, 2019; Stott et al, 2019). In England, the use of Police Liaison Teams (PLTs), comprised of officers skilled in dialogue and wearing distinctive light blue tabards, has been transposed from the world of public order policing and into the field of football policing. This has represented a positive development in encouraging dialogue-based and non-coercive approaches to the policing of football fans, with PLTs even in a position to critique police intelligence and achieve more proportionate policing approaches (Stott et al, 2018). Just as importantly, however, there are significant ethical issues around the creeping use of informants in the policing of Scottish football fans. Such perspectives were recognised by an officer,

There is a huge important value in CHIS, in real time intelligence to prevent disorder. I think that is important. I think it's got to be applied ethically. The purpose of CHIS for me is not who is mouthing off about repealing sectarian laws or, it's got to be about serious crime, serious disorder. Bearing in mind that this is a human being who is going to be at threat if they are burned [exposed publicly as an informant]. (George, police officer)

There are clearly dangers involved in this area of police work. Informants may be exposed and suffer serious harm as a result. Those who are pitched and refuse to become informants may, as has been evidenced in recent media reporting, publicly disclose their experiences, whether through individual choice or self-perceived pressure to 'clear their name' amongst their peers. Such disclosures may have a deleterious effect on trust between fans and the police. Given such consequences the use of informants in the covert policing of football fans, if it is a tactic to be used, must be grounded in a clearly articulated threat of violence and disorder - as George notes above, 'serious crime' - that is accepted as legitimate by the football fans and the wider community. In the absence of this, the use of such covert tactics will continue to be rejected as unnecessary and disproportionate by football fans, feeding a wider narrative of criminalisation and illegitimate forms of policing.

\section{Conclusion}

In conclusion, this paper has addressed, at least in small part, the claim of Loftus and Goold (2012, p. 278) that there is a pressing need for empirical research into the everyday practices of covert police surveillance, including issues concerning the use of informants. Moreover, it has extended the evidence base to include an understanding of how the use of informants, as a covert policing tactic and practice, is received and interpreted by those targeted for recruitment and the wider population in which prospective informants are asked to report upon. This represents a unique contribution to the study of the policing of football, as well as to the wider field of covert policing. Nevertheless, it is 
important to recognise that beyond the aforementioned factors that limit generalisation there are also issues inherent in the sample that qualify the overall findings. Accessing fans who had been pitched proved an exceedingly difficult task, and we were fortunate and grateful to speak to two fans who had lived experience of being pitched to be police informants. That said, this does represent a small number of fans from a larger population that is practically unknowable outside of this highly classified area of police work. We also did not gain access to any football fans who were active police informants. We therefore recognise that the claims made in our paper are limited to some extent by these factors. Nevertheless, we are confident that all research participants, covering football fans, police officers and representatives of clubs, offered credible and authentic accounts of their own perspectives on the use of informants and the covert policing of football fans in Scotland.

Martin Innes (2000, pp. 381-382), in examining the everyday recruitment and management of informants and the use of the information they provide, concluded with a warning against the overreliance on the use of informants in policing, with the instrumental allure of intelligence-led policing running somewhat contrary to the symbolic imagery of policing in Britain as visible and based on the principle of policing by consent. Yet two decades later, and even following the professionalisation of this area of policing and its governance through new legislation and pursuant codes of practice, we concur with this cautionary position. In foregrounding fan experiences our research has uncovered, against a backdrop of intensive police surveillance, not only the 'pitching' of fans but also the disruptive and unsettling effect that this tactic can have on those fans who are pitched or caught up in intensive police surveillance practices. In understanding policing perspectives our research has indicated that the use of informants is frequently justified by the police service as a means to provide actionable intelligence to prevent violence and disorder. Yet in our discussion we caution upon the dangers of this approach in a surveillance society that experiences concomitant 'surveillance creep', particularly in a context where violence and disorder are not accepted by fans as routine occurrences. The use of informants here raises both practical and ethical issues, with the clear potential to exacerbate perceptions of criminalisation amongst football fans and result in a further distancing between fans and the police.

\section{Notes}

1 For a more specific review of literature on the use of informants in policing and law enforcement, see Atkinson (2019).

2 A particular critique here is the construction of a 'British' account, in the absence of research from Scotland.

3 For an interesting international comparison here, see the Mexican account given by Magazine and González (2017).

4 This situation is indicative of a broader malaise in the study of covert policing, despite its growing importance (Mac Giollabhuí et al, 2016, p. 631).

5 This genre has also been an outlet for the disclosure of the stories of undercover police officers who covertly infiltrated networks of football 'hooligans' in England in order to detect and disrupt their activities (see Bannon, 2014).

6 Miller and Selva's research (1994) reports and reflects upon on the activities from the perspective of an informant in the United States of America (USA). Moreover, Miller's more recent work (2011) on the process of 'becoming an informant' draws upon data obtained from in-depth interviews with eighty-four former informants in the USA. 
7 For Lowe (2011), this has justified the use of covert research methods in such settings. More recent research, however, has demonstrated the possibilities for overt research in this area (see Bacon, 2016).

8 Airports have become sites of surveillance - and consequently sites of insecurity and suspicion for communities beyond football fans. Blackwood et al (2013), for example, have highlighted the problematic experiences of Muslims at Scottish airports; sites where they have been subject to routine surveillance and interrogation, with resultant feelings of 'rejection, of hurt and of humiliation'. Importantly, wider research on the experiences of British Muslims at airports has also noted the use of such sites for the purposes of informant recruitment (see Choudhury and Fenwick, 2011).

9 The concept of antisocial behaviour as it intersects with constructions of football fandom and 'risk support' has already been traversed in the literature (see James and Pearson, 2014). 


\section{References}

Andersson, T. , 2001. Swedish football hooliganism, 1900-39. Soccer \& society , 2 (1), 1-18.

Atkinson, C. , 2019. Mind the grass! Exploring the assessment of informant coverage in policing and law enforcement. Journal of policing, intelligence and counter terrorism , 14 (1), 1-19.

Bacon, M. , 2016. Taking care of business: police detectives, drug law enforcement and proactive investigation . Oxford : Oxford University Press.

Bannon, J. , 2014. Running with the firm . London : Ebury Press.

Billingsley, R. , Nemitz, T. , and Bean, P. , 2001. Introduction. In: R.Billingsley, T.Nemitz, and PBean , ed. Informers: policing, policy, practice . London : Routledge, 5-24.

Blackwood, L. , Hopkins, N. , and Reicher, S. , 2013. I know who I am, but who do they think I am? Muslim perspectives on encounters with airport authorities. Ethnic and racial studies , 36 (6), 10901108.

Bowling, B. , Reiner, R. , and Sheptycki, J. , 2019. The politics of the police . Oxford : Oxford University Press.

Brechbühl, A. , Dimech, A.S. , and Seiler, R. 2017. Policing football fans in Switzerland - a case study involving fans, stadium security employees, and police officers. Policing: a journal of policy and practice, Advance Articles. Available at: https://doi.org/10.1093/police/pax086 .

Brodeur, J.P. , 2007. High and low policing in post-9/11 times. Policing: a journal of policy and practice , 1 (1), 25-37.

Choudhury, T. , and Fenwick, H. , 2011. The impact of counter-terrorism measures on Muslim communities. International review of law, computers \& technology , 25 (3), 151-181.

Coalter, F. , 1985. Crowd behaviour at football matches: a study in Scotland. Leisure studies , 4 (1), 111-117.

Doidge, M. , and Lieser, M. , 2016. The importance of research on the ultras: Introduction. Sport in society , $21(6), 833-840$.

Domizio, M.D. , and Caruso, R. , 2015. Hooliganism and demand for football in Italy: Attendance and counterviolence policy evaluation. German economic review , 16 (2), 123-137.

Fyfe, N.R. , 2016. Policing Scotland post reform: Towards a shifting 'culture of control' and a new politics of policing? In: H.Croall, G.Mooney, and MMunro, eds. Crime, justice and society in Scotland . Abingdon : Routledge, 167-181.

Garland, J. , and Rowe, M. , 1999. The 'English disease' - cured or in remission? An analysis of police responses to football hooliganism in the 1990s. Crime prevention and community safety , 1 (4), 3547. 
Hamilton-Smith, N. , and Hopkins, M. , 2013. The transfer of English legislation to the Scottish context: Lessons from the implementation of the football banning order in Scotland. Criminology \& criminal Justice , 13 (3), 279-297.

Hamilton-Smith, N. , McBride, M. , and Atkinson, C. 2019. Lights, camera, provocation? Exploring experiences of surveillance in the policing of Scottish football. Policing \& Society, Latest Articles. Available at: https://doi.org/10.1080/10439463.2019.1696800 .

Heckathorn, D.D. , 1997. Respondent-driven sampling: a new approach to the study of hidden populations. Social problems , 44 (2), 174-199.

Hoggett, J. , and West, O. , 2018. Police liaison officers at football: challenging orthodoxy through communication and engagement. Policing: A Journal of policy and practice. Available at: https://doi.org/10.1093/police/pay032

Hopkins, M. , 2014. Ten seasons of the football banning order: police officer narratives on the operation of banning orders and the impact on the behaviour of 'risk supporters'. Policing \& society , 24 (3), 285-301.

Hutcheon, P. 2018. Police Scotland accused of trying to turn young football fans into paid informants. The Herald, 9 September. Available at: https://www.heraldscotland.com/news/16735745.policescotland-accused-of-trying-to-turn-young-football-fans-into-paid-informants/ .

Innes, M. , 2000. Professionalizing the role of the police informant: the British experience. Policing \& society , 9 (4), 357-383.

James, M. , and Pearson, G. , 2014. Regulating anti-social behaviour and disorder among football spectators. In: SPickard, ed. Anti-social behaviour in Britain: Victorian and contemporary perspectives . New York : Palgrave Macmillan, 296-307.

James, M. , and Pearson, G. , 2015. Public order and the rebalancing of football fans' rights: legal problems with pre-emptive policing strategies and banning orders. Public law , 458-475.

Joern, L. , 2009. Nothing to hide, nothing to fear? Tackling violence on the terraces. Sport in society , $12(10), 1269-1283$.

Kossakowski, R. , 2017. Where are the hooligans? Dimensions of football fandom in Poland. International review for the sociology of sport , 52 (6), 693-711.

Laursen, R.B. , 2019. Danish police practice and national football fan crowd behaviour. Dialogue or coercive force? Soccer \& society , 20 (2), 325-340.

Lavalette, M. , and Mooney, G. , 2013. The Scottish state and the criminalisation of football fans. Criminal justice matters , 93 (1), 22-24.

Law, A. , 2016. Sectarianism, criminalisation and the civilising process in Scotland. In: H.Croall, G.Mooney, and MMunro, ed. Crime, justice and society in Scotland . Abingdon : Routledge, 99-114.

Layton, M. , and Endeacott, R. , 2015. Hunting the hooligans . Croydon : Milo Books.

Loader, I. , and Sparks, R. , 2011. Public criminology? Abingdon : Routledge. 
Loftus, B. , and Goold, B. , 2012. Covert surveillance and the invisibilities of policing. Criminology \& criminal justice , 12 (3), 275-288.

Lowe, D. , 2011. The lack of discretion in high policing. Policing \& society , 21 (2), 233-247.

Lyon, D. , 2001. Surveillance society: monitoring everyday life . Buckingham : Open University Press.

Mac Giollabhuí, S. , Goold, B. , and Loftus, B. , 2016. Watching the watchers: conducting ethnographic research on covert police investigation in the United Kingdom. Qualitative research, $16(6), 630-645$.

Magazine, R. , and González, S.F. , 2017. The criminalization of Mexican football fans and the emergence of the 'Movement of United Mexican Supporters'. In: C.Brandt, F.Hertel, and S.Huddleston, eds. Football fans, rivalry and cooperation . Abingdon : Routledge, 92-107.

Maguire, J. , 2006. Millwall and the making of football's folk devils: revisiting the Leicester period. Sport in society , 9 (4), 599-615.

Marx, G.T. 2005. Seeing hazily (but not darkly) through the lens: some recent empirical studies of surveillance technologies. Law and social inquiry , 30 (2), 385-386.

McBride, M. , 2017. The Offensive Behaviour at Football and Threatening Communications (Scotland) Act 2012 - assessing the case for repeal. Edinburgh law review , 21 (2), 234-239.

McBride, M. , 2018. Rethinking sectarianism: a qualitative exploration of the meanings and experiences of football supporters in the west of Scotland. Unpublished PhD Thesis. University of Glasgow, Glasgow .

Millie, A. , 2009. Anti-social behaviour . Maidenhead : Open University Press.

Miller, J.M. , 2011. Becoming an informant. Justice quarterly , 28 (2), 203-220.

Miller, J.M. , and Selva, L.H. , 1994. Drug enforcement's doubleedged sword: an assessment of asset forfeiture programs. Justice quarterly , 11 (2), 313-335.

Moorhouse, H.F. , 1984. Professional football and working class culture: English theories and Scottish evidence. The sociological review , 32 (2), 285-315.

Moorhouse, H.F. , 1987. Scotland against England: football and popular culture. The international journal of the history of sport , 4 (2), 189-202.

Moorhouse, H.F. , 1991. Football hooligans: old bottle, new whines? The sociological review , 39 (3), 489-502.

Moorhouse, H.F. , 2006. Football hooliganism and the modern world. International review of modern sociology , 32 (2), 257-275.

Newson, M. , et al. , 2018. Brazil's football warriors: social bonding and inter-group violence. Evolution and human behavior , 39 (6), 675-683. 
Norris, C. , and Wilson, D. , 2016. Introduction. In: C. Norris and D. Wilson, eds. Surveillance, crime and social control. Abingdon: Routledge, xi-xxv.

O'Neill, M. , 2004. Policing football in Scotland: the forgotten team. International review for the sociology of sport , 39 (1), 95-104.

O'Neill, M. , 2005. Policing football: social interaction and negotiated disorder. Basingstoke : Palgrave Macmillan.

Pantazis, C. , and Pemberton, S. , 2009. From the 'old' to the 'new' suspect community: examining the impacts of recent UK counter-terrorist legislation. The British journal of criminology , 49 (5), 646666.

Police Scotland . 2016. Covert Human Intelligence Sources (CHIS) Standard Operating Procedure. Available at: http://www.scotland.police.uk/assets/pdf/151934/184779/covert-human-intelligencesources-chis-sop .

Roberts, M. 2019. Independent review of football policing in Scotland. Available at: https://www.scotland.police.uk/assets/pdf/174967/540054/independent-review-of-footballpolicing-in-scotland?view=Standard .

Rookwood, J. , 2017. Managing football hooliganism. In: N.Schulenkorf, and S.Frawley, eds. Critical issues in global sport management . Abingdon : Routledge, 152-163.

Schreiber, A.J. , 2001. Dealing with the devil: an examination of the FBI's troubled relationship with its confidential informants. Columbia journal of law and social problems , 34 (4), 301-368.

Spaaij, R. , 2007. Football hooliganism in the Netherlands: patterns of continuity and change. Soccer \& society , $8(2 / 3), 316-334$.

Spaaij, R. , 2015. Risk, security and technology: governing football supporters in the twenty-first century. In: D.Mastrogiannakis, and C.Dorville, eds. Security and sport mega events: a complex relation. Abingdon : Routledge, 35-51.

Spalek, B. , 2014. Community engagement for counterterrorism in Britain: an exploration of the role of "connectors" in countering takfiri jihadist terrorism. Studies in conflict \& terrorism , 37 (10), 825841.

Stott, C. , 2014. Policing football 'hooliganism': crowds, context and identity. In: M.Hopkins, and J.Treadwell , eds. Football hooliganism: fan behaviour and crime. Basingstoke : Palgrave Macmillan, 248-272.

Stott, C. , Havelund, J. , and Williams, N. , 2019. Policing football crowds in Sweden. Nordic journal of criminology , 20 (1), 35-53.

Stott, C. , Hogget, J. , and Pearson, G. , 2012. 'Keeping the peace': social identity, procedural justice and the policing of football crowds. The British journal of criminology , 52 (1), 381-399.

Stott, C. , West, O. , and Radburn, M. , 2018. Policing football 'risk'? A participant action research case study of a liaison-based approach to 'public order'. Policing \& society , 28 (1), 1-16. 
Stott, C. , and Pearson, G. , 2007. Football 'hooliganism', policing and the war on the 'English disease' . London : Pennant Books.

Stott, C. , Pearson, G. , and West, O. , 2019. Enabling an evidence-based approach to policing football in the UK. Policing: a journal of policy and practice . Available at: https://doi.org/10.1093/police/pay102

Testa, A. , 2018. The all-seeing eye of state surveillance in the Italian football (soccer) terraces: the case study of the football fan card. Surveillance \& society , $16(1), 69-83$.

Tsoukala, A. , 2009. Football hooliganism in Europe: security and civil liberties in the balance . Basingstoke : Palgrave Macmillan.

Whannell, G. , 1979. Football, crowd behaviour and the press. Media, culture and society , 1 (4), 327-342.

Winter, I.C. , 2016. Legal and policing responses to football crowd disorder in Austria. In: A.Tsoukala, G.Pearson, and P.T.M.Coenen, eds. Legal responses to football "hooliganism" in Europe . The Hague : T.M.C. Asser Press, 127-145. 